\title{
TOWARDS INSTITUTIONAL AND ORGANISATIONAL FRAMEWORK FOR THE NATIONAL SPATIAL DATA INFRASTRUCTURE DEVELOPMENT IN SERBIA
}

\section{K INSTITUCIONALNEMU IN ORGANIZACIJSKEMU OKVIRU ZA RAZVOJ NACIONALNE PROSTORSKE PODATKOVNE INFRASTRUKTURE V SRBIJI}

Ljiljana Živković

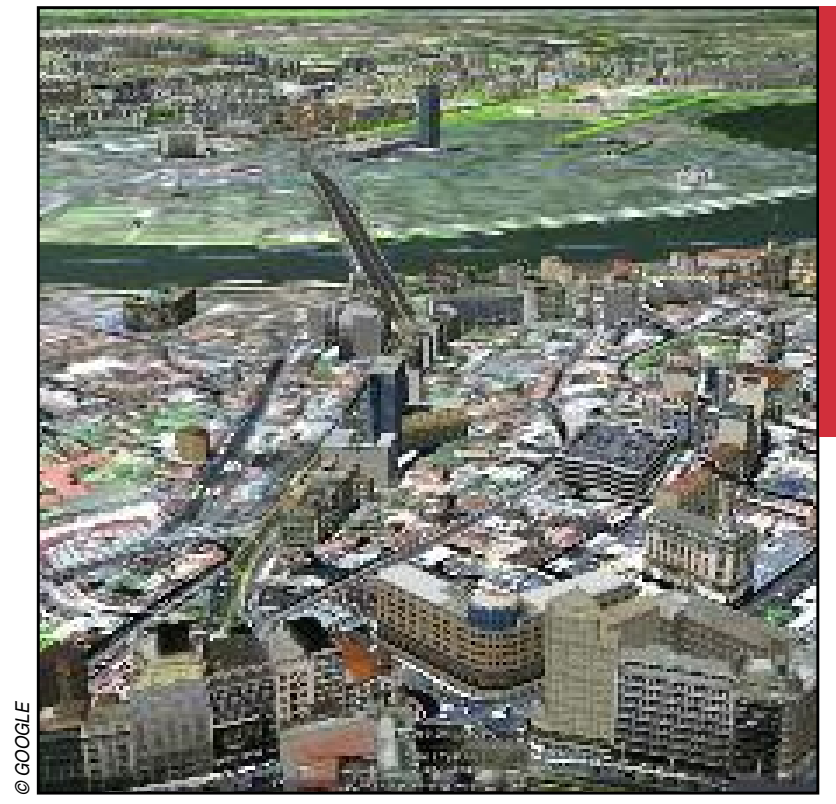

In order for data and information about real life social, economic and environmental phenomena to be available in the format and quality needed for different tasks to be performed by the end-users in Serbia, the Republic Geodetic Authority has launched the initative for National spatial data infrastructure establishment.

Republiški geodetski zavod Srbije je dal pobudo za vzpostavitev nacionalne prostorske podatkovne infrastrukture, s čimer bi zagotovili, da bi bili podatki in informacije 0 dejanskih družbenih, ekonomskih in okoljskih pojavih na razpolago končnim uporabnikom v obliki in kakovosti, potrebni za izvajanje različnih aktivnosti. 


\title{
Towards institutional and organisational framework for the national spatial data infrastructure development in Serbia
}

DOI: $10.3986 / A G S 52108$

UDC: $91: 528.4(497.11)$

COBISS: 1.01

\begin{abstract}
Spatial data infrastructure (SDI) represents a concept that tends to create a context for cooperation and exchange of data, information and knowledge between a particular spatial data community's stakeholders. Thus, the aim of SDI concept development is to establish a common spatially supported platform for making right decisions relevant for economic progress, good governance and sustainable development within a certain domain or jurisdiction, i.e. administrative level. Today, the majority of launched SDI initiatives are on the national level that is also identified as the crucial one for evolution of this concept in general. Additionally, recent research has proven that national SDI (NSDI) developments have become prevailingly social phenomena since interactions between their stakeholders appeared to be critical for achieving purpose of these initiatives, and SDI concept vision in general. Therefore, the aim of this article is to propose an appropriate social, i.e. institutional and organisational framework, for NSDI development in Serbia.
\end{abstract}

KEY WORDS: spatial data infrastructure (SDI); SDI components; SDI development models; SDI hierarchy; national SDI (NSDI); institutional and organisational framework; Serbia

The article was submitted for publication on May 20, 2011.

ADDRESS:

Ljiljana Živković, Ph. D.

Majke Jevrosime 22, 11000 Belgrade, Serbia

E-mail: liliana.zivkovic@gmail.com

\section{Contents}

1 Introduction 191

2 Methodology 191

3 Spatial data infrastructure (SDI) 192

3.1 Definition, evolution and current development 192

3.2 Hierarchical organisation and role of national SDI

4 Analysis with results: Current status and impact analysis of NSDI initiative in Serbia 195

4.1 Legal framework and development strategy 195

4.2 NSDI components and their impacts 197

5 Discussion: proposal of Serbian

NSDI institutional framework and organisational model $\quad 198$

6 Conclusion 200

7 References 201 


\section{Introduction}

At the end of the 1990s, the former US Vice President Al Gore presented a vision of Digital Earth (DE) (Gore 1998) as a multi-resolution and three-dimensional presentation that would enable discovering, visualisation and true understanding of an enormous quantity of geo-referenced data and information about social phenomena and environment on our planet (Craglia et al. 2008).

Among other things, DE vision assumes the development of a spatial data infrastructure (SDI) concept, an idea of spatially literate society and spatially enabled government that would lead to transformation of the present Information into Knowledge Society paradigm (Williamson et al. 2006). This latter paradigm postulates the implementation of spatially referenced models within the SDI concept that would based on already available information-enable creation and exchange of knowledge between the public, private and non-governmental sectors. This knowledge is neccessary for making the right decisions, critical for economic development, good governance and environmental sustainability in general.

Masser (2006) classifies current research in the domain of SDI concept development into four areas (diffusion, evolution, data exchange and hierarchy). For this article, research within the SDI hierarchical organisation area is important. Recently, these research undertakings pointed out that accomplishment of SDI concept advantages has depended on the development model selected for the SDI initiative implementation (Feeney et al. 2001, 2, 3), that is, on SDI organisational and institutional framework (Kok and Van Loenen 2005).

In 2008, the Serbian Government initiated the development of the NSDI initative. Relying on the latest technological advantages and developed countries with SDI-related experiences, Serbia is expected to develop NSDI hierarchy and gain concept advantages faster and more efficiently (Williamson 2004; Nedović-Budić et al. 2007).

Therefore, the aim of this article is to identify the knowledge necessary for the implementation of the NSDI concept, creating a proposal for an institutional and organisational framework for its efficient and effective development in Serbia.

\section{Methodology}

In order to propose optimal institutional preconditions and organisational structure for efficient and effective development of the NSDI initative in Serbia based on experiences of other countries, my research methodology has involved collection and reading of selected articles and documentation that provided me with knowledge needed for better understanding and conceptualisation of the SDI development issue in general.

The research material was chosen based on its capabilities to respond to SDI development related research questions, like: What is the content and aim of the SDI concept and its development in general? What approaches have been applied to SDI development so far, and what are their implications on the SDI concept in general? Are there some lessons learnt relevant to SDI initatives and their development? Who is responsible for SDI development? What kind of an organisational model and structural concept does SDI have? What is the national SDI concept position, and what is its role within the SDI paradigm development in general?

Thus, articles and documentation used to compile relevant analytical framework were selected based on: (1) relevance of their topics to the research questions posed, (2) SDI initiatives that were used as case studies, as well as (3) the number of citations/quotations in SDI-relevant publications. Among the chosen articles, prevalent were those with case studies coming from the countries that are known as the most advanced in SDI concept development, which represent today's best practices for other countries, particularly for Serbia, which is at the beginning of SDI concept establishment. In spite of their potential importance for the research subject, differences between public administrations and political systems of the researched countries' SDI development experiences were not taken into account as relevant research variables.

The first research step included identification of the SDI concept and the aim of its development in general. This step was necessary in order for the nature of the SDI concept and its ultimate development goal to be defined and later related to the needed organisational and institutional framework. 
Then, this definition was put in the context of SDI development approaches recognised in literature to date. Based on the 7 criteria used by Rajabifard et al. (2002) for assessment of the existing SDI initiatives, advantages and disadvantages of the two identified basic approaches to the development of SDI concepts (either on local, regional or national level) were identified. These criteria are important, because they revealed the complex nature of the recently emerged - third-SDI development approach that represents a combination - composition- of the previous two basic approaches. Actually, this composite SDI development approach has been suggested to less developed countries, like Serbia, that need to grasp the benefits of the SDI concept in general quickly, efficiently and effectively. In other words, this means that the proposed organisational and institutional framework for the NSDI concept in Serbia has to attain and support the characteristics of both basic development approaches. For example, a future Serbian NSDI organisational structure has to support and be evaluated based on the presence of: both short- and long- term planning activities (criterion: time-frame commitment); achievement of both periodical as well as ongoing results (criterion: measures of progress); developed mechanisms for different kinds of stakeholders' involvement and management (criterion: membership of development); applied management styles (criterion: management of development); existing motivation factors for stakeholders to be involved in the NSDI development process (criterion: motivation for development); scopes of responsibilities and types of decision-making processes (criterion: political/administrative function).

Finally, pyramid-like hierarchical organisational model of the SDI concept drove my research towards identification of potentially recognised relationships and impacts that national SDI initatives could have on other SDI levels, especially those within national SDI jurisdictions. In this research, the impact was defined and treated as a potential role each SDI component on one level could have in building the same component on other levels of the SDI pyramid. Therefore, preformed impact analysis of SDI had an objective to assess and determine the significance of organisational and institutional component-related solutions for NSDI development.

\section{Spatial data infrastructure (SDI)}

\subsection{Definition, evolution and current development}

The SDI concept is usually defined as a set of policies, technologies and standards necessary for efficient collection, management, access, exchange and usage of geospatial data and knowledge within geospatial data communities on global, regional, national and local levels (Rajabifard et al. 2002).

Thus, as Feeney et al. (2001) claim, the main objective of SDI development is to build a context where producers and users of geospatial data, information and knowledge on any administrative level - i.e. jurisdiction - could cooperate and utilise these resources in a cost-efficient and cost-effective way for economically efficient, socially responsible and ecologically sustainable decision-making.

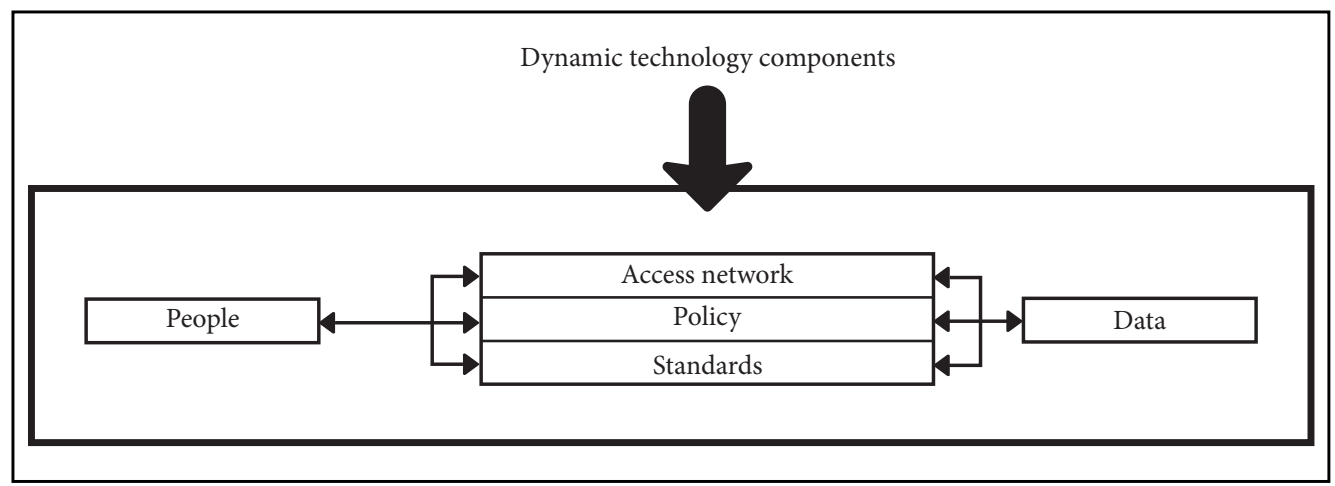

Figure 1: SDI components and their relations (Rajabifard etal. 2001; source: Mohammadi etal. 2008, 407). 
Dynamic technology components

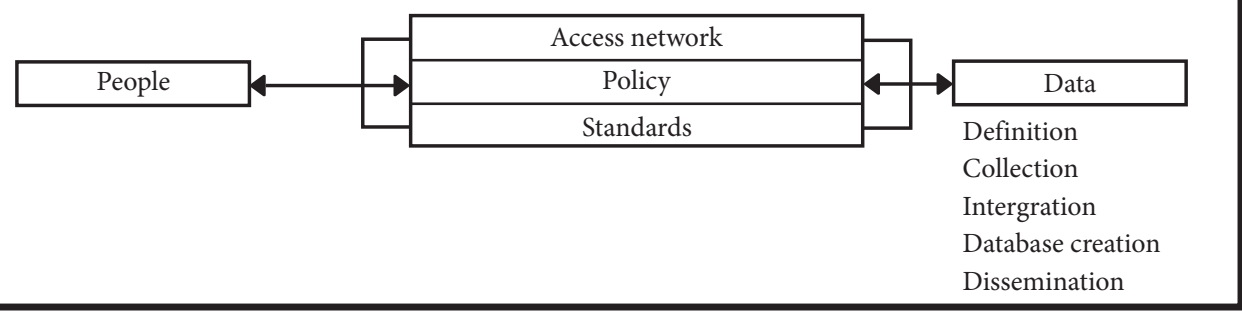

A) Product-based model

Social System

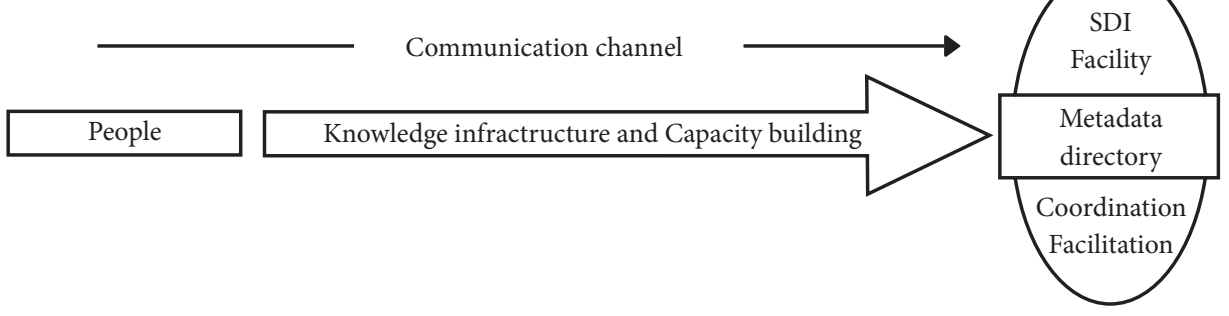

B) Process-based model

Figure 2: Product- and process- based models for SDI concept development (Rajabifard et al. 2002, 15).

Following the above definition, SDI is usually described as a constellation of five basic components: people; access networks; policies; standards; and data (Rajabifard and Williamson 2002).

Since the first initiatives were launched, relationships between SDI components have been changing (Craglia et al. 2008, 147, 148). In the beginning, the focus of SDI concept development was on single-jurisdiction strategic partnerships aimed at creation of concrete products and/or services in the short run. Later, relationships between people, i.e. social component, and data component became critical for the SDI concept

Table 1: Criteria for SDI development model determination (Rajabifard etal. 2002, 18).

\begin{tabular}{lll}
\hline SDI development model assessment criteria & Product-based model & Process-based model \\
\hline Motivation for development & $\begin{array}{l}\text { integrating the existing data with the aim to } \\
\text { develop a common fundamental database } \\
\text { within a spatial data community }\end{array}$ & $\begin{array}{l}\text { establishing the links between people and } \\
\text { data to facilitate exchange and sharing within } \\
\text { a spatial data community }\end{array}$ \\
\hline Expected outcomes & $\begin{array}{l}\text { an SDI database/warehouse, } \\
\text { data-exchange agreement }\end{array}$ & an active directory linking data and people \\
\hline Management of development & implementation & coordination \\
\hline Membership of development & participatory, representative, compulsory & voluntary \\
\hline Measures of progress & punctuated deliverables & $\begin{array}{l}\text { ongoing establishment and maintenance } \\
\text { of a framework or conduit for spatial data } \\
\text { for a community }\end{array}$ \\
\hline Political/administrative function & & intra-jurisdictional and inter-jurisdictional \\
\hline Time-frame commitment & intra-jurisdictional, inter-jurisdictional & long-term planning \\
\hline
\end{tabular}


development. Thus, today the focus of development is on management of different SDI stakeholders' rights, restrictions and responsibilities against geospatial data through various and long-term cross-jurisdictional partnerships (Feeney et al. 2001, 4, 5; Rajabifard and Williamson 2002).

Thus, the originally dominant short-term product-based approach, i.e. development model, oriented towards SDI content building, has been complemented later with a process-based approach to establishment of communication conduit that needs to secure long-term commitment of all SDI stakeholders to cooperate and exchange data, information and knowledge between jurisdictions (Rajabifard and Williamson 2002).

Adoption of either one of two SDI development approaches - or models - depends directly on a mandate that a particular jurisdiction needs to establish (Feeney et al. 2001). However, it was also possible to implement a composite product-process approach that secures advantages of both models to a particular jurisdiction, making it more flexible as a whole. This is due to the initial raising of social commitment to SDI concept building, thus securing a common leadership and trust necessary for data, information and knowledge sharing.

\subsection{Hierarchical organisation and role of national SDI}

Like any other organisation, the SDI social component has an organisational model that consists of three functional layers: strategic, management and operational. Therefore, in accordance with traditional organisation theory postulates, as well as modern organisational research oriented to implementation of ICTtechnologies (Mintzberg 1983; Živković 2009), SDI structure has been commonly described as a hierarchy, i.e. a spatial pyramid (Rajabifard et al. 2002).

Also, Rajabifard et al. (2000) claim that (identical) hierarchical structure and organisational model are repeating within each SDI jurisdiction, as well as within each level of the pyramid (Rajabifard et al. 2002). In general, at the bottom of the SDI pyramid there is the operational level; in the middle, there are administrators, researchers and managers; and at the top strategic level of the hierarchy, there are decision-makers who determine strategic directions for the SDI future development.

Besides the organisation theory, and the needs for division of roles and responsibilities within SDI social component for concept development purposes, Rajabifard et al. (2000) find that evolution of SDI spatial hierarchies relies on three important properties of the hierarchy theory as well:

- Whole-part property - where an element on the higher hierarchical level consists of one or more elements from the lower level;

- Janus effect - assumes that an element on a certain hierarchical level has two different faces, i.e. relations: to element-wholes on a hierarchically higher level, and to element-parts on a lower level; and

- Near decomposability property - this property is related to the nesting of the systems within larger sub-systems.

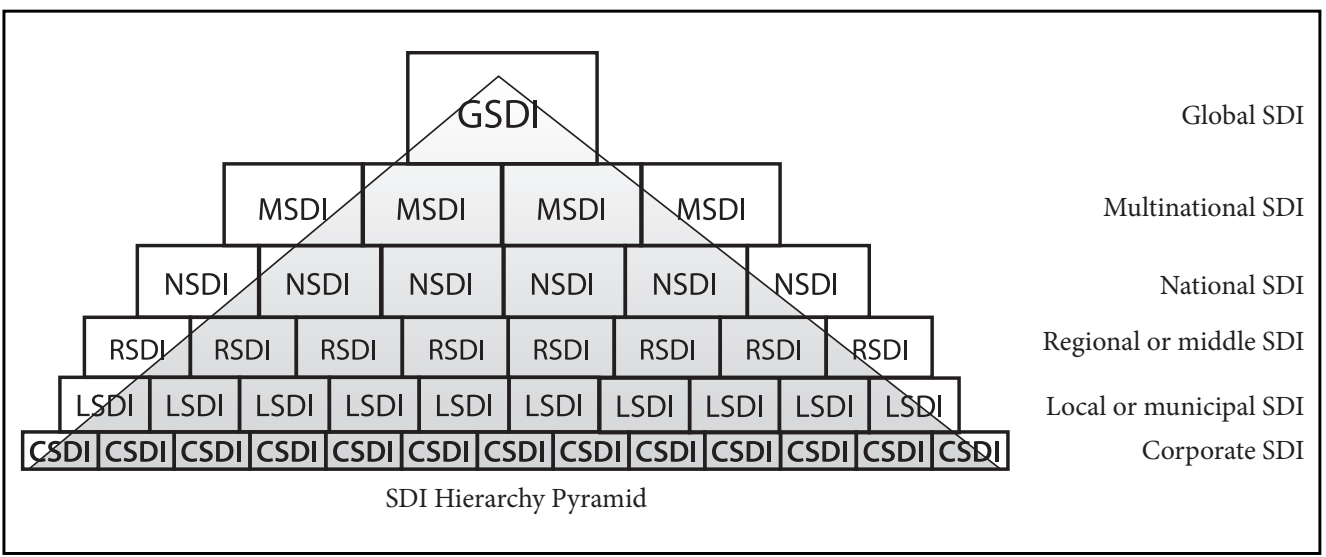

Figure 3: SDI global hierarchical structure, i.e. spatial pyramid, is the result of different mandates of the SDIs' jurisdictions on different levels, as well as within the same level (adapted: Rajabifard etal. 2002). 
Thus, while three organisational layers of SDI hierarchy should take different roles and responsibilities for SDI concept development, these hierarchical properties indicate the need for each layer to build the capacity for management of intra- and cross- jurisdictional relations, i.e. to be aware of its own impact on the development of other jurisdications.

Finally, due to the facts that (1) the main sources of key geospatial datasets are at national levels, and (2) political leadership and institutional-organisational frameworks at the same levels have critical influence on availability and accessibility of these datasets (Kok and Van Loenen 2005), the significance and role of national SDI (NSDI) initiatives for reaching the Knowledge Society paradigm is beyond doubt.

Furthermore, a decisive impact that NSDI initiatives have on the development of every other level, i.e. jurisdictions, within the SDI hierarchy, and thus on the Global SDI concept in general, has been confirmed by a comprehensive analysis performed by Rajabifard et al. (2000). (Table 2)

Table 2: NSDI initiative directly impacts development of components on other levels within GSDI pyramid (adapted: Rajabifard etal. 2000, 7).

\begin{tabular}{lcccc}
\hline SDI component & \multicolumn{4}{c}{ National SDI impact } \\
\cline { 2 - 5 } & Global SDI & Multinational SDI & Regional SDI & Local SDI \\
\hline Policy & $\checkmark$ & $\checkmark$ & $\checkmark$ & $\checkmark$ \\
Fundamental datasets & $\checkmark$ & $\checkmark$ & $\checkmark$ & $x$ \\
Technical standards & $x$ & $\checkmark$ & $\checkmark$ & $\checkmark$ \\
Access network & $\checkmark$ & $\checkmark$ & $\checkmark$ & $\checkmark$ \\
People & $\checkmark$ & $\checkmark$ & $\checkmark$ & $\checkmark$ \\
\hline
\end{tabular}

\section{Analysis with results: Current status and impact analysis of NSDI initiative in Serbia}

Compared to developed countries, developing countries are facing the challenge to institute the NSDI concept faster, more efficiently and at lower cost (Williamson 2004). Due to the NSDI concept's critical effect on the development of the SDI paradigm in general, these countries - like Serbia - need to prioritise and carefully plan NSDI jurisdiction development (Kok and Van Loenen 2005).

Thus, being aware of the NSDI jurisdiction impact (Rajabifard et al. 2000), as well as of its social component's critical role for the concept implementation and sustainability as a whole (Kok and Van Loenen 2005), the rest of the article describes, compares and analyses the current state of NSDI-oriented activities in Serbia, and ultimately proposes an optimal institutional and organisational framework for it.

In accordance with the compiled research framework (chapter 2), the position, definition and aim of the NSDI initiative in Serbia were first identified and analysed. Then, (given) the importance of the social component and its role were recognised through identification of the selected NSDI development model. Simultaneously, awareness about the organisational structure and hierarchical properties of the NSDI initative were analised, while the nature of the organisational and institutional framework and completeness was evaluated pursuant to the maturity model (chapter 4.1). Finally, following the NSDI development status description, potential impacts of this SDI jurisdiction and its components on lower hierarchical levels were analised (chapter 4.2).

\subsection{Legal framework and development strategy}

An initiative for the development of the NSDI concept in Serbia was launched on part of the Republic Geodetic Authority (RGA) that collects geospatial datasets fundamental for the establishment of the SDI paradigm (Rajabifard et al. 2000; Nedović-Budić et al. 2007).

In the Law on State Survey and Cadastre (hereinafter: the Law) (Official Gazette of the Republic of Serbia, No. 72/2009, 18/2010), NSDI initiative has been defined as a »strategy, technology, rules, standards and human resources needed for collection, processing, storage, access, exchange and optimal usage of geospatial data on the Republic of Serbia territory«. 


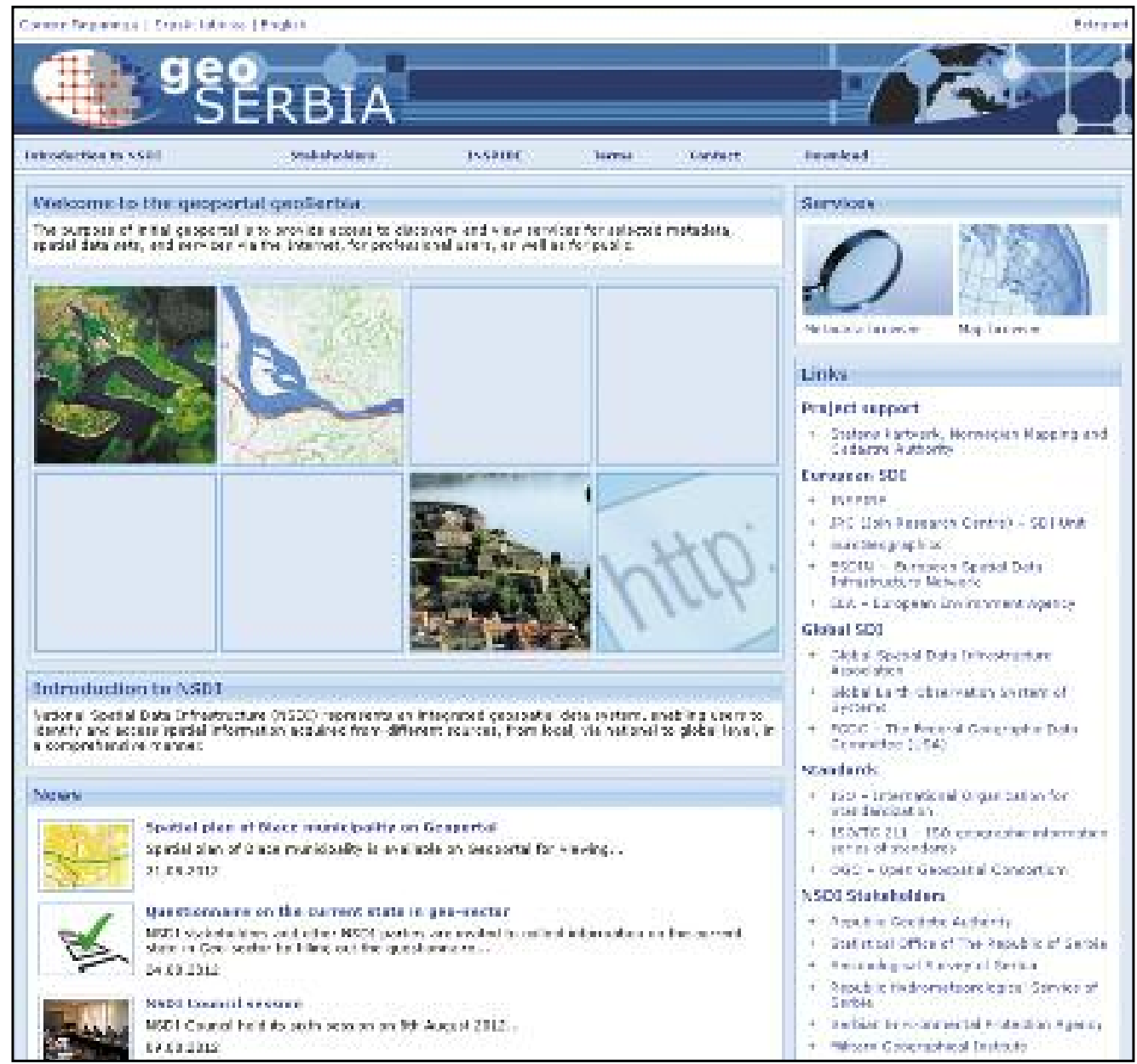

Figure 4: The launched national geoportal »GeoSerbia« will support retrieving, discovering, viewing and, in future, exchanging existing geospatial datasets in Serbia, needed for performance of different tasks and operations. Also, geoportal role is to introduce NSDI concept among its participants, stakeholders and the Serbian population in general (@ geoSerbia).

Also, this Law clearly prescribes adjustment of future Serbian NSDI solutions to the pan-European SDI initiative rules, namely the INSPIRE Directive. This Directive is aimed towards the development of European infrustructure for spatial information needed for the creation of EU environmental policies and management of relevant activities; also, European multinational SDI community is building on common rules for all Member States' NSDIs in the domain of: metadata; spatial data sets and services; network services and technologies; agreements on sharing, use and access.

Further, the above mentioned Law underscores the commitment to implement a composite product-process development model for NSDI, which puts a special emphasis on 'people' and 'data' components' relationships management.

However, the Law neither prescribes a prospective NSDI hierarchy development, nor does it acknowledge the importance and impact of this SDI jurisdication level in Serbia on the development of others in future.

Besides the Law, the Strategy for Establishment of NSDI Initiative in Serbia 2009-2012 (hereinafter: the Strategy) (Official Gazette of the Republic of Serbia, No. 81/2010) introduces plural 'we', i.e. community common, NSDI vision statement. 
Furthermore, the NSDI Council was established, consisting of representatives of the relevant authorities, chaired by the RGA Director. Recently, this Council adopted the Mid-term Program of Works for NSDI Establishing and Maintenance 2011-2015, and established thematic work groups with tasks to perform and coordinate national spatial data community's activities in three domains: communication, technical framework and legal framework.

Also, national geoportal GeoSerbia was launched in 2009 with the primal aim to support easier geospatial data search and finding.

Table 3: Serbian NSDI initiative maturity from organisational and institutional framework perspective (adapted: Kok and Van Loenen 2005, 706).

\begin{tabular}{lllll}
\hline Aspect & Stage of maturity & & & \\
\cline { 2 - 5 } & Stand alone & Exchange/standardisation & Intermediary & Network \\
\hline Vision & $\begin{array}{l}\text { Focus on individual } \\
\text { organisation }\end{array}$ & $\begin{array}{l}\text { Developed with all } \\
\text { stakeholders }\end{array}$ & Implementation & $\begin{array}{l}\text { Commonly shared, and } \\
\text { frequently reviewed }\end{array}$ \\
\hline Leadership & $\begin{array}{l}\text { Focus on individual } \\
\text { organisation }\end{array}$ & Questioned & Accepted & $\begin{array}{l}\text { Respected by all } \\
\text { stakeholders }\end{array}$ \\
\hline Communication & $\begin{array}{l}\text { Focus on individual } \\
\text { organisation }\end{array}$ & $\begin{array}{l}\text { Open between public } \\
\text { parties }\end{array}$ & $\begin{array}{l}\text { Open between all } \\
\text { stakeholders }\end{array}$ & $\begin{array}{l}\text { Open and interactive } \\
\text { between all }\end{array}$ \\
\hline Self-organising ability & $\begin{array}{l}\text { Passive problem } \\
\text { recognition }\end{array}$ & $\begin{array}{l}\text { Neutral problem } \\
\text { recognition }\end{array}$ & $\begin{array}{l}\text { Actively helping to solve } \\
\text { identified problems }\end{array}$ & $\begin{array}{l}\text { Actively working } \\
\text { on innovations }\end{array}$ \\
\hline
\end{tabular}

Finally, based on the current status of institutional preconditions and organisational context (Kok and Van Loenen 2005), NSDI initiative in Serbia is in its initial stand alone phase of maturity. For example, although the vision statement within the Strategy is written in plural 'we', it hasn't been explicitly adopted yet - by official cooperation agreement - as common on part of other NSDI stakeholders. Therefore, NSDI community leadership on part of the multi-institutional NSDI Council is rather an informal one, and it is still exercised by the RGA (its NSDI Department). Consequently, besides the established Work group for communication activities, in this phase of the Serbian NSDI development communication is generally limited to meeting intra-organisational needs on part of each participant. Lastly, it seems that the majority of geospatial community's stakeholders in Serbia still identify problems passively, keeping focus exclusively on the legally delegated tasks, and reducing community self-organising ability to the minimum. These attitudes are reflected in the absence of information on structured core metadata elements on geoportal for each uploaded data set, or the absence of systematic generation and adoption of common spatial data standards and legal framework in Serbia.

\subsection{NSDI components and their impacts}

Identical to others, Serbian NSDI initiative includes five basic components (Rajabifard et al. 2002) that are described within the mentioned Strategy $(2010,5)$ : data; standards; access network; people; and policy.

Except for policy, all other components are prescribed by the Law. Also, the above mentioned Mid-term Programme envisages a certain number of activities, targets and goals for those components.

Refering to the already identified significant impact that NSDI initatives have on the development of other SDI jurisdictions upper and lower in the hierarchy (Table 2.), in the case of Serbian NSDI jurisdiction potential impacts should be expected for all components, except for the influence of national SDI fundamental datasets development on building of local SDI ones.

In absence of a policy document, impacts that emerging NSDI components have on hierarchically lower levels, and NSDI pyramid in general in Serbia, are analysed below.

Concerning the data component, a part of key geodata sets in Serbia is collected and managed on national level, while others are collected and maintained on local level, usually within organisational units that are constituents of governmental/public institutions established on national level (key geodata sets include: administrative boundaries, cadastral maps, geographic names, land uses, land covers, topographic features, etc.). Without a relevant data policy, the rate of geospatial data and information sharing and exchange between and within different SDI levels and jurisdictions in Serbia depends merely on goodwill of NSDI stakeholders. 


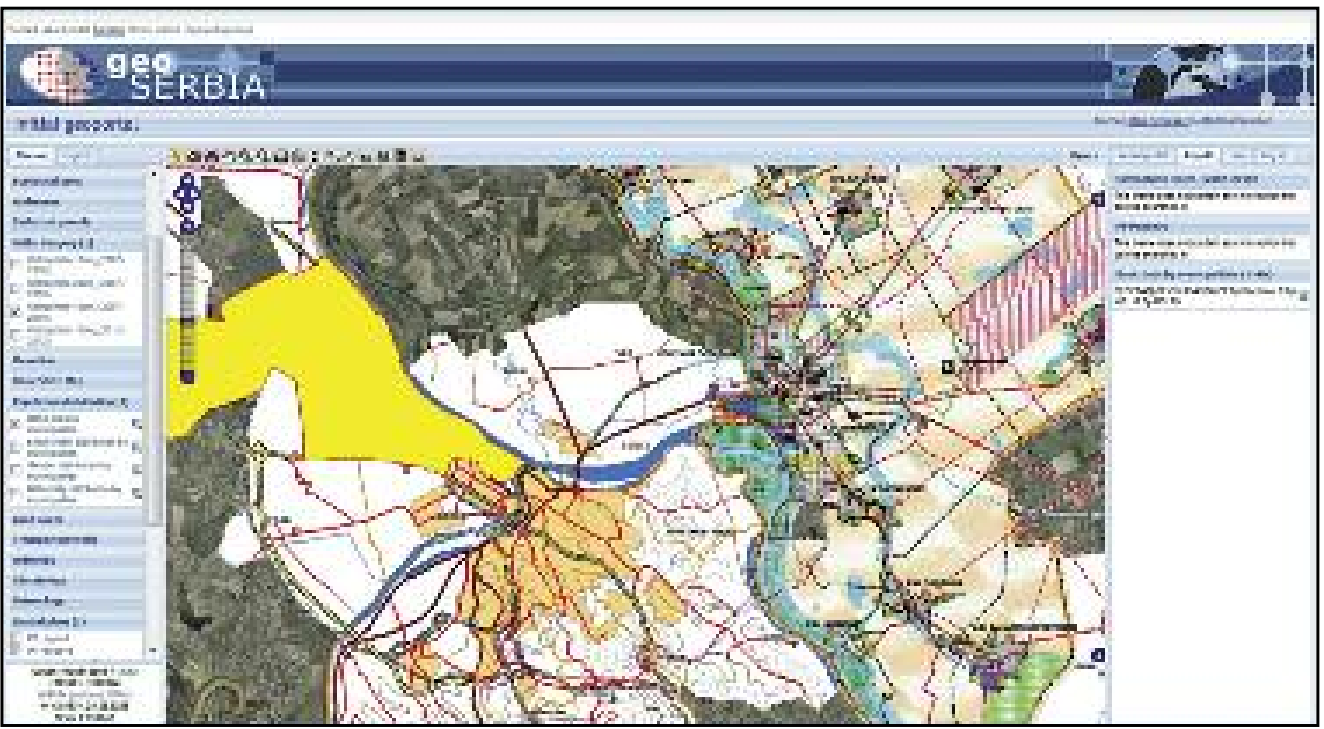

Figure 5: Implementation of common technical standards within the emerging geospatial data community provides capabilities for integral viewing, combining and analysis of different geospatial datasets coming from different sources, thus providing possibilities for making the right decisions on actions in future (@ geoSerbia).

Also, besides the already implemented ISO technical standards (prescribed by the INSPIRE Directive) for core metadata and XML schema definition on national level, prospective NSDI development needs to identify and adopt other technical and non-technical standards on all other levels. These standards would assure the presently missing (1) socio-technical consistency of the NSDI initiative in Serbia, and enable the needed (2) integration and interoperability of data from different SDI sources and jurisdictions on national level, and wider (Mohammadi et al. 2008, 404).

Likewise, regardless of the increasing needs for data and information for decision-making processes on local, regional and national levels, access to geospatial data today is generally poor due to unevenly developed network technologies throughout Serbia (Nedović-Budić et al. 2007). Thus, a future NSDI policy should stress that availability of geodata in a cost-efficient and cost-effective manner in Serbia would directly rely on technological solutions that have to be implemented within each functional layer and organisational level (Curdt et al. 2009).

Finally, although voluntarism is not a usual cooperation model in Serbia today, and cross-sectoral teams and multidisciplinary projects are rather exceptions, in future NSDI's people component should consist of all geospatial community's stakeholders and interest groups from all levels and every jurisdiction: either private or public sector actors; national or local organisations. Like, for example, the Republic Agency for Spatial Planning, Statistical Office of the Republic of Serbia, Faculty of Geography, Geographic Institute Jovan Cvijic, regional authorities, municipalities, NGOs, commercial data providers, offices of foreign-funded projects (like GIZ, USAID, WB and other project implementation units), etc.

\section{Discussion: proposal of Serbian NSDI institutional framework and organisational model}

After describing current initial preconditions for implementation of the NSDI concept in Serbia (chapter 4.1), and analysis of the status and needs for the development of basic SDI components on each level within national SDI jurisdication (chapter 4.2), an optimal organisational and institutional context for efficient and effective NSDI development will be discussed here. 


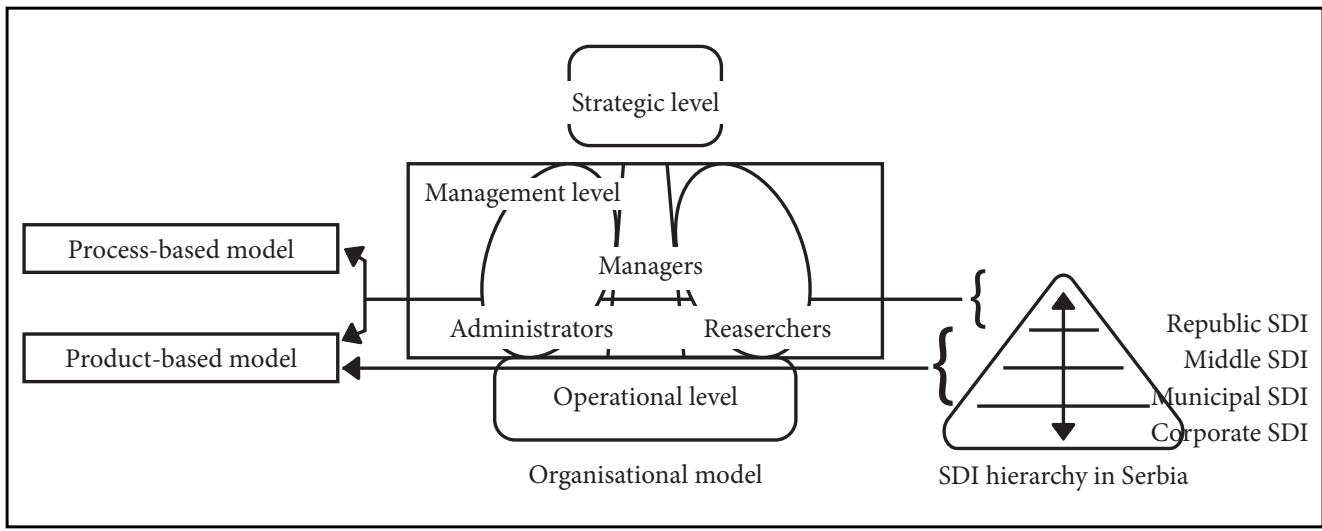

Figure 6: General NSDI hierarchy with organisational structure and development models - proposal (adapted: Rajabifard etal. 2002, 17; Mintzberg 1983).

Following the INSPIRE Directive's recommendations, and experiences of those countries that have the longest histories and are on the forefront of NSDI concept development, like Norway, the Netherlands, USA, Australia, UK, Sweden, etc. (Rajabifard et al. 2002), Serbia should invest particular efforts in building social - people - component within all functional layers of NSDI jurisdiction. In this respect, the above stated countries' best practices include: establishment of an independent body for NSDI development, like in the Netherlands, Norway or Australia; education of staff from different stakeholders' organisations about internationally adopted technical and non-technical standards; introduction of courses/classes to the topic of (N)SDI at universities.

And, although some listed countries have moved or are moving from product- to process- based NSDI development model, Serbia should implement a composite product-process model for the NSDI initative development. Composite model would secure NSDI development process with the efficiency and flexibility necessary for overcoming structural challenges in Serbia, like: the lack of fundamental geospatial datasets, and the existing technical and non-technical inconsistencies. Besides the advantages mentioned, this (composite) model has been recognised as the most frequent one within European nations (Rajabifard et al. 2002) that are obliged to apply the INSPIRE Directive, which Serbia - as an aspiring country for EU membership - should follow as well.

Thus, the proposed composite model for the Serbian NSDI development should provide advantages of both - product and process- approaches. However, on each level of NSDI pyramid, properties of one of those two basic development models should be dominant (Mintzberg 1983; Živković 2009).

In other words, strategic level of NSDI organisational model (Figure 3) should adopt process-based development model, since it would be responsible for long-term decision-making activities, including:

- Creation and implementation of NSDI policy and strategy;

- Communication and coordination of decisions implementation on all levels;

- Coordination of work groups' activities; and

- Making other decisions relevant to sustainability of this concept in Serbia.

On the middle management level of the NSDI pyramid, tasks relevant for the product-based model should dominate, since administrators, managers and researchers on this level would be engaged in short-term development of concrete NSDI services and products. In general, managers from different levels and public sector organisations throughout Serbia should be responsible for the development of NSDI-relevant management tools. Researchers from institutes, universities and other knowledge-oriented organisations in Serbia should be engaged in the creation and dissemination of knowledge and innovations towards fast, efficient and effective development of NSDI. Finally, administrators from different levels of public sector should contribute by preparing different policy proposals, the implementation of which would support optimal institutional conditions for evolution of the NSDI initiative in Serbia.

Lastly, at the operating level of the NSDI structure, product-based development model properties should be dominant. This level of the NSDI hierarchy should be comprised of all municipalities' stakeholders in 
Serbia that would manage spatial data resources within their jurisdictions in accordance with common NSDI standards and procedures prescribed by the strategic level, and monitored and evaluated by management level (Carrera and Ferreira 2007).

\section{Conclusion}

Upon formal launching of the NSDI initiative in Serbia, an appropriate organisational and institutional framework needs to be identified towards securing its optimal development and implementation within country specific conditions, particularly (1) lack of key geodata sets and (2) absence of cross-organisational communication and cooperation.

Relying on experiences and lessons learnt from countries that represent the best practices in NSDI development domain, composite development approach should be adopted. On the one hand, adoption of a composite development model should secure a balanced and comprehensive capacity building approach to NSDI organisational structure in Serbia; for example, responsibilities for NSDI content (data sets) development and conduit (communication, cooperation, access, etc. channel) establishment could be shared equally and optimally between NSDI stakeholders. On the other hand, a composite model should provide awareness and mobilisation of the people component that has proven to be critical for accomplishing objectives of the SDI concept in general; for example, involvement of people early on in NSDI development process would create ownership, trust and motivation among stakeholders for this concept.

Also, before building basic NSDI components and a pertinent jurisdiction hierarchy, an appropriate organisational and institutional framework with clear stakeholders' roles, rights, restritions and responsibilities against the data component needs to be defined. This framework should support critical issues, like:

- Work of NSDI Council at the top strategic level that should have a strong leadership role;

- Work of competent work groups/project teams on the middle level that should work on solutions needed for achievement of NSDI advantages in Serbia; and

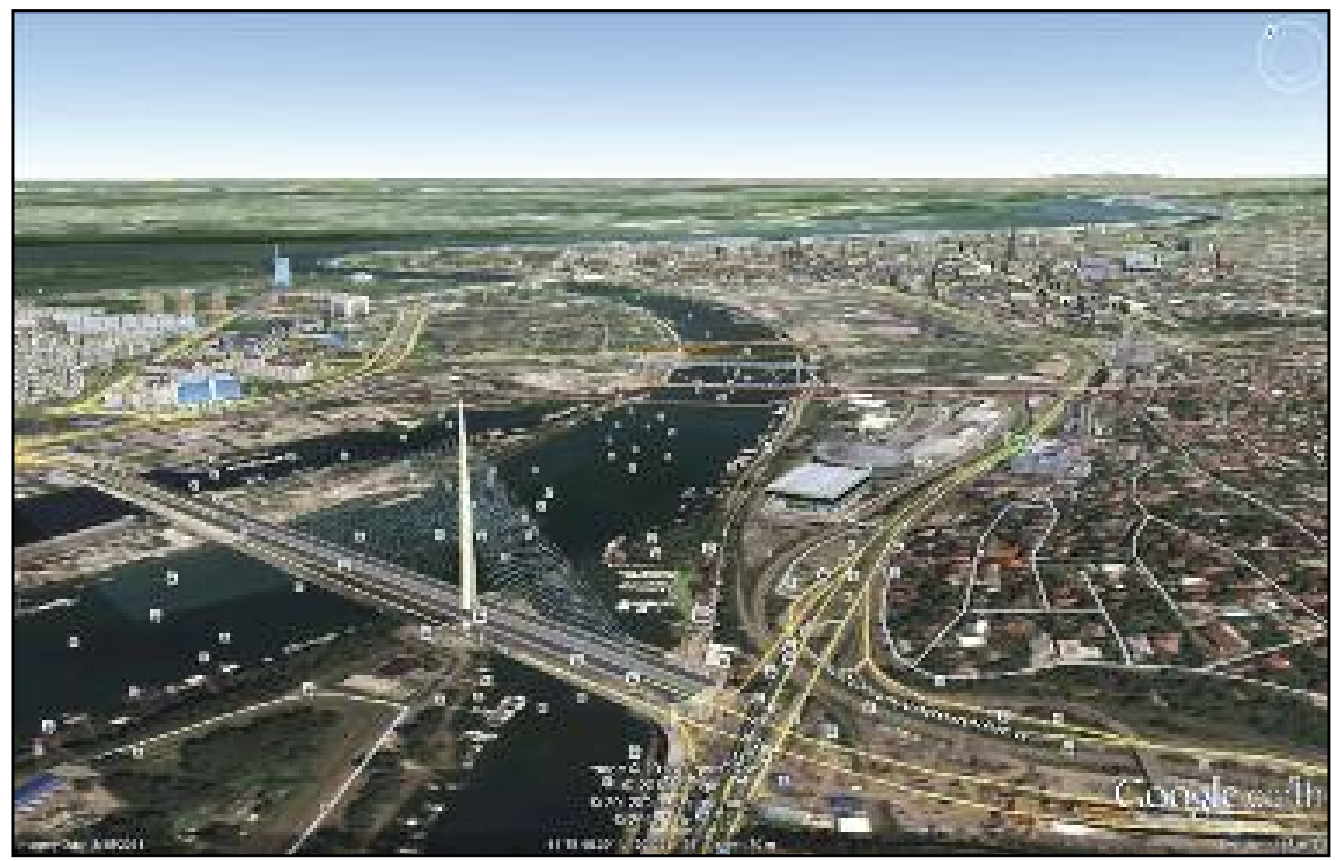

Figure 7: After building prerequisited databases and creating the needed knowledge, Serbian NSDI will be a reliable platform for modelling and simulating real phenomena and their dynamics, providing all end-users with comprehensive and real-time understanding of the living environment (@) Google). 
- Establishment of stable communication channels, coordination mechanisms and commitment for implementation and adoption of NSDI standards on the local level.

In future, led by the NSDI Council and coordinated by a common policy and strategy, the actors involved should create an environment where the needs of all spatial communities' stakeholders and interest groups would be satisfied, while increasing benefits of information and knowledge network would be a motive for reaching self-organising ability and Knowledge Society in Serbia.

Finally, in order for the solutions proposed in this article to be implemented in the Serbian NSDI, it is necessary to conduct a series of research undertakings that would point to optimal solutions for each SDI component, as well as for other socio-technical phenomena related to the development and evolution of this concept.

\section{References}

Carrera, F., Ferreira, J. 2007: The Future of Spatial Data Infrastructures: Capacity-building for the Emergence of Municipal SDIs. International Journal of Spatial Data Infrastructures Research 2. Ispra.

Craglia, M., Goodchild, M. F., Annoni, A., Camara, G., Gould, M., Kuhn, W., Mark, D., Masser, I., Maguire, D., Liang, S., Parsons, E. 2008: Next-Generation Digital Earth. International Journal of Spatial Data Infrastructures Research 3. Ispra. DOI: 10.2902/1725-0463.2008.03.art9.

Curdt, C., Hoffmeister, D., Waldhoff, G., Bareth, G. 2009: Implementation of a metadatabase for a regional SDI for soil-vegetation-atmosphere modelling. International Journal of Spatial Data Infrastructures Research GSDI-11. Ispra.

Directive 2007/2/EC of the European Parliament and of the Council of 14 March 2007 establishing an Infrastructure for Spatial Information in the European Community (INSPIRE). Official Journal of the European Union, European Parliament and of the Council of the European Union L108, 50. Luxembourg.

Feeney, M., Rajabifard, A., Williamson, I. P. 2001: Spatial Data Infrastructure Frameworks to Support Decision-Making for Sustainable Development. Cartagena.

Gore, A. 1998: The Digital Earth: Understanding our planet in the $21^{\text {st }}$ century. Internet: http://www.isde5.org/ al_gore_speech.htm (3.12.2010).

Internet: http://www.geosrbija.rs (7.8.2010).

Kok, B., Van Loenen, B. 2005: How to assess the success of National Spatial Data Infrastructures?. Computers, Environment and Urban Systems 29. Amsterdam. DOI: 10.1016/j.compenvurbsys.2004.02.001.

Law on State Survey and Cadastre. Official Gazette of the Republic of Serbia 72/2009, 18/2010. Belgrade.

Masser, I. 2006: What's Special about SDI Related Research? International Journal of Spatial Data Infrastructures Research 1. Ispra.

Republic Geodetic Authority 2011: Srednjoročni program radova na osnivanju i održavanju NIGP-a za period od 1. januara 2011. do 31. decembra 2015. godine. Belgrade.

Mintzberg, H. 1983: Structure in Fives: Designing Effective Organizations. New Jersey.

Mohammadi, H., Rajabifard, A., Williamson, I. 2008: Spatial Data Integrability and Interoperability in the Context of SDI. The European Information Society-Taking Geoinformation Science One Step Further. Amsterdam.

Nedović-Budić, Z., Jokić, V., Dželebžić, O., Budhathoki, N. R. 2007: Spatial Data Infrastructure and Its Initiation in Serbia. Sustainable Spatial Development of Town and Cities 1. Belgrade.

Rajabifard, A., Feeney, M., Williamson, I. P. 2002: Directions for the Future SDI Development, International Journal of Applied Earth Observation and Geoinformation 4-1. Enschede. DOI: 10.1016/S03032434(02)00002-8.

Rajabifard, A., Williamson, I. P. 2002: Spatial Data Infrastructures: An Initiative to Facilitate Data Sharing, Global Environmental DBs - Present Situation and Future Directions 2. Hong Kong.

Rajabifard, A., Williamson, I. P., Holland, P., Johnston, G. 2000: From Local to Global SDI initiatives: a pyramid of building blocks. $4^{\text {th }}$ GSDI Conference Proceedings, Cape Town.

Strategy for Establishment of the NSDI Initiative in Serbia 2009-2012. Official Gazette of the Republic of Serbia 81/2010. Belgrade.

Williamson, I. P. 2004: Building SDIs - The Challenges Ahead. $7^{\text {th }}$ GSDI Conference Bangalore. 
Williamson, I. P., Rajabifard, A., Binns, A. 2006: Challenges and Issues for SDI Development. International Journal of Spatial Data Infrastructures Research 1. Ispra.

Živković, L. 2009: Information and communication technologies support to the Republic spatial planning system transformation. Department for Spatial Planning, Faculty of Geography, University of Belgrade. Belgrade. 



\section{K institucionalnemu in organizacijskemu okviru za razvoj nacionalne prostorske podatkovne infrastrukture v Srbiji}

DOI: $10.3986 /$ AGS52108

UDK: 91:528.4(497.11)

COBISS: 1.01

IZVLEČEK: Prostorska podatkovna infrastruktura (PPI) je koncept, ki se uporablja za izdelavo konteksta za sodelovanje in izmenjavo podatkov, informacij in znanja med deležniki določene prostorsko podatkovne skupnosti. Cilj razvoja koncepta PPI je vzpostavitev skupne, prostorsko podprte platforme za sprejemanje pravilnih odločitev, pomembnih za gospodarski napredek, dobro upravljanje in trajnostni razvoj znotraj določene domene ali pristojnosti, tj. na določeni upravni ravni. Danes večina novih pobud, povezanih s PPI, poteka na državni ravni, ki je tudi ključna raven za splošni razvoj koncepta. Poleg tega so nedavne raziskave potrdile, da je razvoj nacionalnih prostorskih podatkovnih infrastruktur (NPPI) v prvi vrsti družbeni fenomen, saj so se odnosi med deležniki izkazali za odločilne pri doseganju ciljev teh pobud in vizije koncepta PPI na splošno. Zato je cilj tega članka predlagati primeren družbeni, tj. institucionalni in organizacijski okvir za razvoj NPPI v Srbiji.

KLJUČNE BESEDE: prostorska podatkovna infrastruktura (PPI), sestavine PPI, razvojni modeli PPI, hierarhija PPI, nacionalna PPI (NPPI), institucionalni in organizacijski okvir, Republika Srbija

Uredništvo je prejelo prispevek 20. maja 2011.

NASLOV:

dr. Ljiljana Živković

Majke Jevrosime 22, 11000 Beograd, Srbija

E-pošta: liliana.zivkovic@gmail.com

\section{Vsebina}

1 Uvod 205

2 Metodologija 205

3 Prostorska podatkovna infrastruktura (PPI) 206

3.1 Opredelitev, evolucija in trenutni razvoj 206

3.2 Hierarhična organizacija in vloga nacionalne PPI 208

$4 \quad$ Analiza $\mathrm{z}$ rezultati: trenutno stanje in analiza učinka pobude NPPI v Srbiji 209

4.1 Zakonski okvir in razvojna strategija 209

4.2 Sestavine NPPI in njihovi učinki 210

5 Razprava: predlog srbskega institucionalnega

6 Sklep 212

7 Literatura 213 


\section{Uvod}

Ob koncu 90. let prejšnjega stoletja je bivši podpredsednik ZDA Al Gore predstavil vizijo digitalne Zemlje (DZ) (Gore 1998) kot večresolucijske, trirazsežnostne predstavitve, ki bi pomagala pri raziskovanju, vizualizaciji in pravilnem razumevanju ogromne količine geografsko opredeljenih podatkov in informacij o družbenih pojavih in okolju na našem planetu (Craglia in ostali 2008).

Med drugim vizija DZ predvideva razvoj koncepta prostorske podatkovne infrastrukture (PPI), ideje o prostorsko opismenjeni družbi in prostorsko usposobljeni vladi, ki bi vodila v preobrazbo iz današnje paradigme informacijske družbe v paradigmo družbe znanja (Williamson in ostali 2006). Slednja predpostavlja uvajanje prostorsko referenciranih modelov s konceptom PPI, ki bi - na podlagi dostopnih podatkovomogočal nastanek in izmenjavo znanja med javnimi, zasebnimi in nevladnimi sektorji. To znanje je potrebno za sprejemanje pravih odločitev in zelo pomembno za gospodarski razvoj, dobro upravljanje in okoljsko trajnost na splošno.

Trenutne raziskave na področju domene razvoja koncepta PPI Masser (2006) razvršča v štiri področja (širjenje, evolucija, izmenjava podatkov in hierarhija). Za potrebe tega članka so pomembne predvsem študije hierarhične organizacije PPI. V zadnjem času raziskave navajajo, da je doseganje prednosti koncepta PPI odvisno od razvojnega modela, izbranega za izvajanje pobude PPI (Feeney in ostali 2001, 2 in 3), torej od organizacijskega in institucionalnega okvira PPI (Kok, Van Loenen 2005).

Leta 2008 je Vlada Republike Srbije začela z razvojem pobude NPPI. Pričakovati je, da bo Srbija hierarhijo NPPI razvila na podlagi tehnološkega napredka zadnjih let in izkušenj razvitih držav s PPI in da bo tako hitreje in bolj učinkovito izkoristila prednosti tega koncepta (Williamson 2004, 8 in 9; Nedović-Budić in ostali 2007).

Namen tega članka je torej ugotoviti, kakšno znanje je potrebno za uvedbo koncepta NPPI, s katerim bomo lahko ustvarili predlog institucionalnega in organizacijskega okvira za smotrn in učinkovit razvoj v Srbiji.

\section{Metodologija}

Za izdelavo predloga optimalnih institucionalnih predpogojev in organizacijske strukture za smotrn in učinkovit razvoj pobude NPPI v Srbiji, izdelanega na podlagi izkušenj drugih držav, sem v svojo raziskovalno metodologijo vključila zbiranje in prebiranje izbranih člankov in dokumentacije, s čimer sem pridobila znanje, potrebno za boljše razumevanje in konceptualizacijo razvoja PPI na splošno.

Raziskovalno gradivo je bilo izbrano glede na stopnjo podajanja raziskovalnih odgovorov na vprašanja, povezana z razvojem PPI, kot so: Kakšna sta vsebina in cilj koncepta PPI in njegov razvoj na splošno? Kakšni pristopi so se do danes uporabljali za razvoj PPI in kakšne posledice so ti imeli za razvoj koncepta PPI na splošno? Ali smo pri tem pridobili kakšne pomembne izkušnje, pomembne za pobude PPI in njihov razvoj? Kdo je odgovoren za razvoj PPI? Kakšen organizacijski model in strukturni koncept ima PPI? Kakšno je stanje na področju nacionalnega koncepta PPI in kakšno vlogo ima ta znotraj razvoja paradigme PPI na splošno?

V skladu s tem so bili članki in dokumentacija, uporabljeni za sestavo ustreznega analitičnega okvira, izbrani glede na: (1) ustreznost njihove tematike glede na postavljena raziskovala vprašanja, (2) pobude PPI, ki so bile uporabljene kot študije primera, in tudi (3) število citatov/navedb v revijah, pomembnih za PPI. Med izbranimi članki so prevladovali tisti, ki so vsebovali študije primera iz držav, ki smo jih prepoznali kot najbolj napredne pri razvoju koncepta PPI in ki predstavljajo primere dobre prakse za druge države, predvsem za Srbijo, ki je še na začetku vzpostavitve koncepta PPI. Razlik med sistemi javne uprave in političnimi sistemi raziskovanih držav navkljub morebitnemu velikemu pomenu za predmet raziskovanja nismo obravnavali kot pomembne raziskovalne spremenljivke.

Prvi raziskovalni korak je bil določitev koncepta PPI in cilj njegovega razvoja na splošno. Ta korak je bil nujen za opredelitev narave koncepta PPI in njegovega končnega razvojnega cilja in kasneje povezan s potrebnim organizacijskim in institucionalnim okvirjem.

Ta opredelitev je bila nato postavljena v kontekst različnih pristopov $\mathrm{k}$ razvoju PPI, ki jih omenja tudi strokovna literatura. Na podlagi sedmih kriterijev, ki so jih za oceno obstoječih pobud PPI uporabili Rajabifard in ostali (2002), smo določili prednosti in slabosti dveh osnovnih pristopov k razvoju koncepta PPI 
(na lokalni, regionalni ali nacionalni ravni). Ti kriteriji so pomembni, saj so razkrili kompleksno naravo nedavno nastalega - tretjega - pristopa k razvoju PPI, ki je kombinacija - sestav - prejšnjih dveh osnovnih pristopov. Ta sestavljeni pristop k razvoju PPI je bil predlagan za manj razvite države, kot je Srbija, in naj bi služil kot podpora razumevanju koristi koncepta PPI na splošno, in to hitro, smotrno in učinkovito. To z drugimi besedami pomeni, da mora predlagani organizacijski in institucionalni okvir za koncept PPI $\mathrm{v}$ Srbiji doseči in podpirati značilnosti obeh osnovnih razvojnih pristopov. Tako bo morala prihodnja srbska organizacijska struktura NPPI podpirati naslednje dejavnike in bo na podlagi njih tudi ocenjena: kratkoročne in dolgoročne načrtovalske aktivnosti (kriterij: zaveza k časovnemu razporedu); doseganje rednih in sprotnih rezultatov (kriterij: merila napredka); razvoj mehanizmov za različne vrste vključevanja deležnikov in upravljanja (kriterij: članstvo v razvoju); načini upravljanja (kriterij: upravljanje razvoja); obstoječi motivacijski dejavniki za deležnike v procesu razvoja PPI (kriterij: motivacija za razvoj); obseg odgovornosti in vrsta postopka sprejemanja odločitev (kriterij: politična/upravna funkcija); in podobno.

Hierarhični organizacijski model koncepta PPI v obliki piramide je mojo raziskavo nazadnje povedel $\mathrm{k}$ določitvi potencialno prepoznanih razmerij in učinkov, ki jih imajo nacionalne pobude PPI lahko na druge ravni PPI, predvsem znotraj nacionalnih pristojnosti PPI. V tej raziskavi je bil učinek opredeljen in obravnavan kot potencialna vloga, ki bi jo lahko imela vsaka sestavina PPI na neki ravni pri izgradnji iste sestavine na drugih ravneh piramide PPI. Zato je bil cilj izvedene analize vpliva PPI oceniti in določiti pomen organizacijskih in institucionalnih komponentnih rešitev za razvoj NPPI.

\section{Prostorska podatkovna infrastruktura (PPI)}

\subsection{Opredelitev, evolucija in trenutni razvoj}

Koncept PPI večinoma opredeljujemo kot skupek politik, tehnologij in standardov, potrebnih za učinkovito zbiranje, upravljanje, dostop, izmenjavo in uporabo geoprostorskih podatkov in znanja znotraj geoprostorskih podatkovnih skupnosti na globalni, regionalni, nacionalni in lokalni ravni (Rajabifard in ostali 2002).

Kot trdijo Feeney in ostali (2001), je poglavitni cilj razvoja PPI izgradnja konteksta, v katerem bi proizvajalci in uporabniki geoprostorskih podatkov, informacij in znanja, na katerem koli upravnem nivoju tj. pristojnosti -, sodelovali in ta sredstva uporabili na stroškovno učinkovit in smotrn način za gospodarsko učinkovito, družbeno odgovorno in ekološko trajnostno sprejemanje odločitev.

V skladu z zgornjo opredelitvijo PPI običajno opisujemo kot skupek petih temeljnih sestavin: ljudi, dostopovnih omrežij, politik, standardov in podatkov (Rajabifard in Williamson 2002).

Od prvih pobud in vse do danes se razmerja med sestavinami PPI spreminjajo (Craglia in ostali 2008, 147 in 148). Na začetku je bil razvoj koncepta PPI usmerjen v enosistemsko strateško partnerstvo, katerega cilj je bil nastanek konkretnih proizvodov in/ali storitev na kratek rok. Kasneje so za razvoj koncepta PPI postala bistvena razmerja med ljudmi, to je družbena komponenta, in podatkovna komponenta. Tako

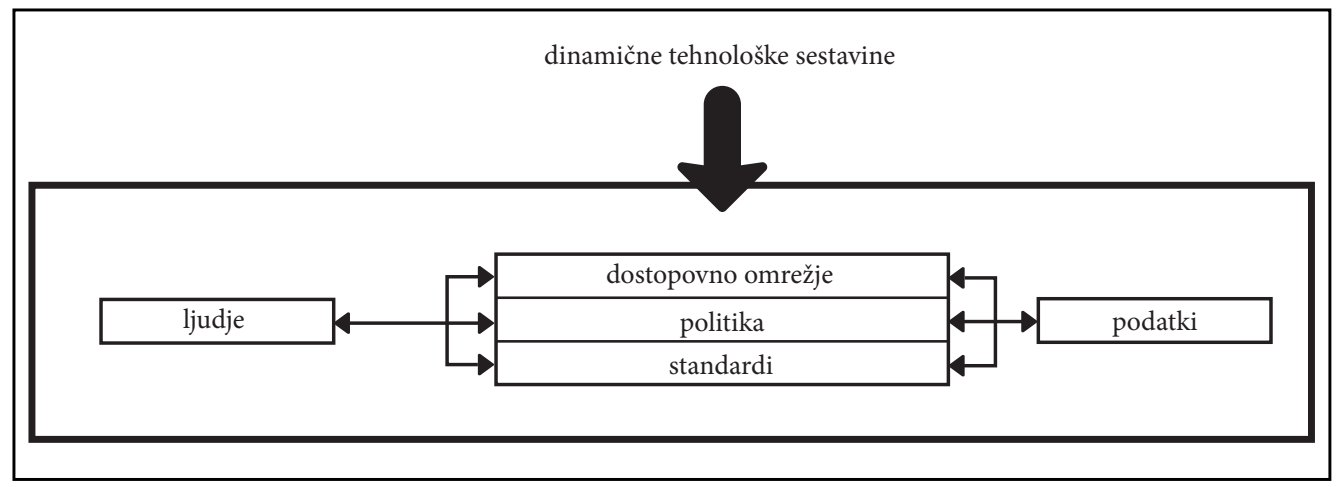

Slika 1: Sestavine PPI in njihova medsebojna razmerja (Rajabifard in ostali 2001; Mohammadi in ostali 2008). 
dinamične tehnološke sestavine

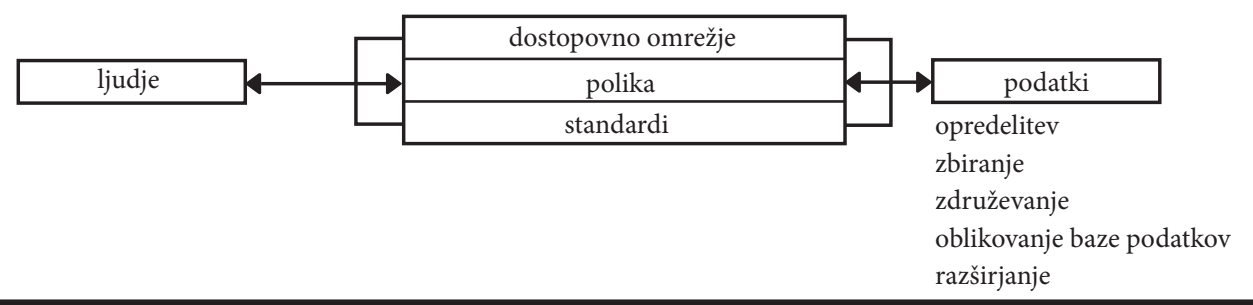

A) proizvodni model

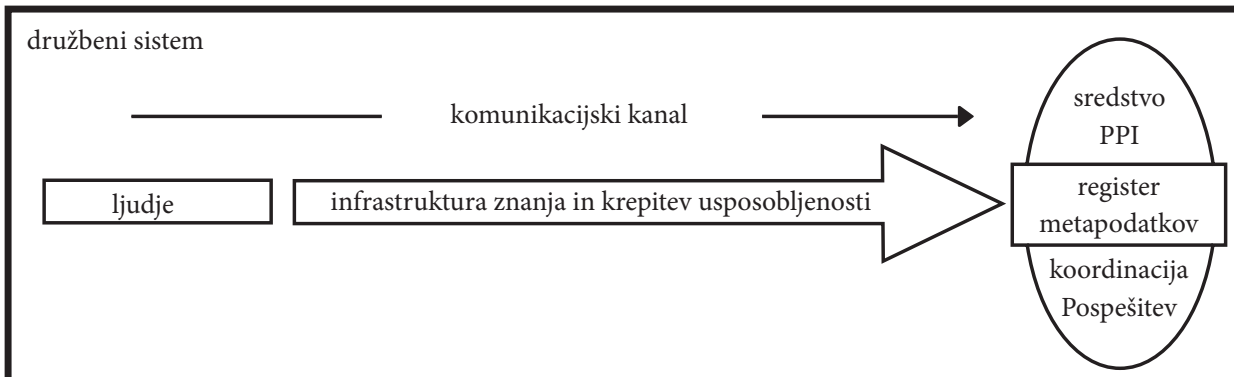

B) procesni model

Slika 2: Proizvodni in procesni model za razvoj koncepta PPI (Rajabifard in ostali 2002).

je danes razvoj osredotočen na upravljanje različnih pravic deležnikov v PPI, omejitev in odgovornosti do geoprostorskih podatkov skozi različna in dolgoročna medpristojnostna partnerstva (Feeney in ostali 2001, 4 in 5; Rajabifard, Williamson 2002).

Tako je bil sprva prevladujoči kratkoročni proizvodni pristop, tj. razvojni model, ki je bil usmerjen v vsebinsko izgradnjo PPI, kasneje dopolnjen s procesnim pristopom za vzpostavitev komunikacijske poti, ki naj zagotovi dolgoročno zavezo vseh deležnikov PPI k sodelovanju in izmenjavi podatkov, informacij in znanja med različnimi ravnmi pristojnosti (Rajabifard, Williamson 2002).

Sprejetje katerega koli od dveh razvojnih pristopov PPI - ali modelov - je neposredno odvisno od pristojnosti, ki jih določeni sistem vzpostavi (Feeney in ostali 2001). Navkljub temu pa je bila možna tudi

Preglednica 1: Kriteriji za določitev razvojnega modela PPI (Rajabifard in ostali 2002, 18).

\begin{tabular}{lll}
\hline ocenjevalni kriteriji razvojnega modela ppi & proizvodni model & procesni model \\
\hline motivacija za razvoj & $\begin{array}{l}\text { vključitev obstoječih podatkov za razvoj } \\
\text { skupne temeljne podatkovne baze znotraj } \\
\text { prostorsko podatkovne skupnosti }\end{array}$ & $\begin{array}{l}\text { vzpostavitev povezav med ljudmi in podatki } \\
\text { za omogočanje izmenjave in skupne uporabe } \\
\text { znotraj prostorsko podatkovne skupnosti }\end{array}$ \\
\hline pričakovani rezultati & $\begin{array}{l}\text { podatkovna baza ppi/skladišče, } \\
\text { dogovor o izmenjavi podatkov }\end{array}$ & aktiven register, ki povezuje podatke in ljudi \\
\hline upravljanje razvoja & izvajanje & koordinacija \\
\hline članstvo v razvoju & udeležbeno, predstavitveno, obvezno & prostovoljno \\
\hline merila napredka & poudarjeni končni rezultati & $\begin{array}{l}\text { stalno vzpostavljanje in vzdrževanje okvira } \\
\text { ali poti za prostorske podatke za neko } \\
\text { skupnost }\end{array}$ \\
\hline politična/upravna funkcija & & znotrajpristojnostna in medpristojnostna \\
\hline časovna zaveza & znotrajpristojnostna, medpristojnostna & dolgoročno načrtovanje \\
\hline
\end{tabular}


izvedba sestavljenega proizvodno-procesnega pristopa, ki izkorišča prednosti obeh modelov v določenem pristojnostnem sistemu in ga zato v celoti dela bolj fleksibilnega. Razlog temu je začetno dvigovanje družbene požrtvovalnosti v zvezi z izgradnjo koncepta PPI, sčimer se zagotavlja skupno vodenje in zaupanje, potrebno za skupno uporabo podatkov, informacij in znanja.

\subsection{Hierarhična organizacija in vloga nacionalne PPI}

Kot katera koli druga organizacija ima tudi družbena komponenta PPI organizacijski model, ki sestoji iz treh funkcionalnih plasti: strateške, upravljavske in operativne. Zato v skladu s predpostavkami tradicionalne organizacijske teorije in sodobnih organizacijskih raziskav, usmerjenih v uvajanje IKT-tehnologij (Mintzberg 1983; Živković 2009), strukturo PPI pogosto opisujemo kot hierarhijo, tj. prostorsko piramido (Rajabifard in ostali 2002).

Poleg tega Rajabifard in ostali (2000) ugotavljajo, da se (identična) hierarhična struktura in organizacijski model ponavljata znotraj vsake pristojnosti PPI kot tudi znotraj vsake ravni piramide (Rajabifard in ostali 2002). Splošno gledano je na dnu piramide PPI operativna raven; v sredini so upravno osebje, raziskovalci in upravljavci; in na vrhu je strateška raven hierarhije z nosilci odločanja, ki določajo strateške usmeritve za prihodnji razvoj PPI.

Poleg organizacijske teorije in potreb po delitvi vlog in odgovornosti znotraj družbene komponente PPI za potrebe razvoja koncepta Rajabifard in ostali (2000) ugotavljajo, da je evolucija prostorskih hierarhij PPI odvisna od treh pomembnih lastnosti hierarhične teorije:

- lastnosti celota-del - kjer element na višji hierarhični ravni vsebuje enega ali več elementov iz spodnje ravni;

- Janusovega učinka - ta predpostavlja, da ima element na določeni hierarhični ravni dva različna obraza, tj. razmerja: do celot elementa na hierarhično višji ravni in do delov elementa na nižji ravni; in

- lastnosti skorajšnje dekompozicije - ta lastnost je v povezavi z gnezdenjem sistemov znotraj večjih podsistemov.

Medtem ko tri organizacijske plasti hierarhije PPI prevzemajo različne vloge in odgovornosti za razvoj koncepta PPI, pa te hierarhične lastnosti nakazujejo potrebo, da vsaka plast izgradi zmožnost upravljanja znotraj- in medpristojnostnih razmerij, tj. da se zavedajo svojega lastnega učinka na razvoj drugih pristojnosti.

Ker je (1) glavni vir ključnih geoprostorskih naborov podatkov na nacionalni ravni in ker (2) politično vodstvo in institucionalno-organizacijski okviri na istih ravneh pomembno vplivajo na razpoložljivost in dostopnost teh podatkov (Kok, Van Loenen 2005), je pomembnost in vloga pobud nacionalnih PPI (NPPI) za doseganje paradigme družbe znanja brez dvoma pomembna.

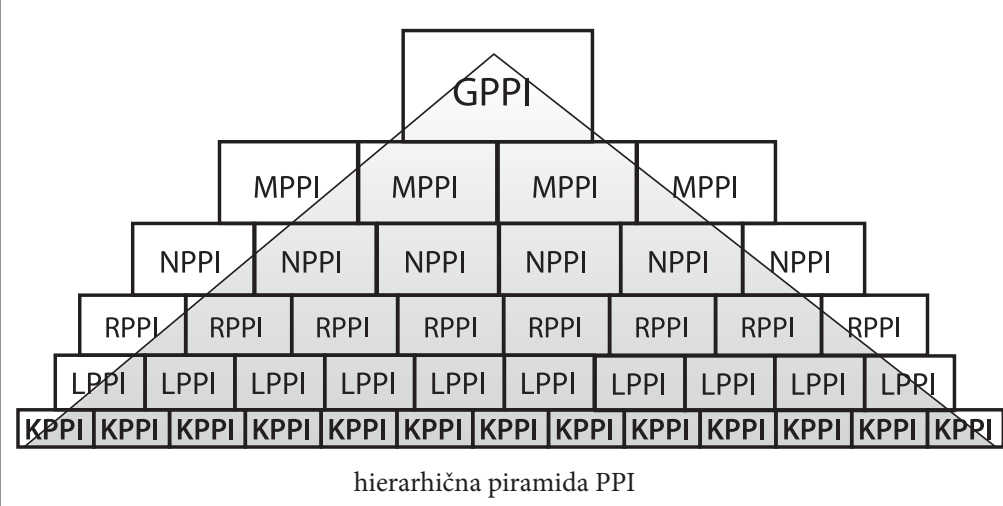

globalna PPI

večnacionalna PPI

nacionalna PPI

regionalna ili srednja PPI

lokalna ili občinska PPI

korporacijska PPI

Slika 3: Globalna hierarhična struktura PPI, tj. prostorska piramida, je rezultat različnih pristojnosti pristojnostnega sistema PPI na različnih ravneh kot tudi znotraj iste ravni (povzeto po: Rajabifard in ostali 2002). 
Poleg tega je izčrpna analiza, ki so jo izvedli Rajabifard in ostali (2000), (preglednica 2), potrdila odločilni vpliv, ki ga imajo pobude NPPI na razvoj vseh drugih ravni, tj. pristojnosti, znotraj hierarhije PPI in tudi na globalni koncept PPI.

Preglednica 2: Pobuda NPPI neposredno vpliva na razvoj sestavin na drugih ravneh znotraj GPPI-piramide (privzeto po: Rajabifard in ostali 2000, 7).

\begin{tabular}{lcccc}
\hline sestavina ppi & \multicolumn{4}{c}{ učinek nacionalne ppi } \\
\cline { 2 - 5 } & globalna ppi & večnacionalna ppi & regionalna ppi & lokalna ppi \\
\hline politika & $\checkmark$ & $\checkmark$ & $\checkmark$ & $\checkmark$ \\
temeljne zbirke podatkov & $\checkmark$ & $\checkmark$ & $\checkmark$ & $x$ \\
tehnični standardi & $x$ & $\checkmark$ & $\checkmark$ & $\checkmark$ \\
dostopovno omrě̌je & $\checkmark$ & $\checkmark$ & $\checkmark$ & $\checkmark$ \\
ljudje & $\checkmark$ & $\checkmark$ & $\checkmark$ & $\checkmark$ \\
\hline
\end{tabular}

\section{Analiza $z$ rezultati: trenutno stanje in analiza učinka pobude NPPI v Srbiji}

V primerjavi z razvitimi državami imajo države v razvoju pred seboj izziv, da bi koncept NPPI vpeljale hitreje, bolj učinkovito in z manjšimi stroški (Williamson 2004). Zaradi pomembnih posledic, ki ga ima koncept NPPI na splošni razvoj paradigme PPI, morajo te države - kot je Srbija - določiti prednostni red in skrbno načrtovati razvoj pristojnosti NPPI (Kok, Van Loenen 2005).

Zavedajoč se učinka pristojnosti NPPI (Rajabifard in ostali 2000) in pomembnega vpliva družbene komponente PPI na uvajanje koncepta in trajnost na splošno (Kok, Van Loenen 2005), je v nadaljevanju članka opisano, primerjano in analizirano trenutno stanje aktivnosti, povezanih z NPPI v Srbiji, in na koncu predlagan optimalni institucionalni in organizacijski okvir.

V skladu z nastalim raziskovalnim okvirom (poglavje 2) smo najprej ugotavljali in analizirali položaj, opredelitev in cilje pobud NPPI v Srbiji. Nato smo z določitvijo izbranega razvojnega modela NPPI ugotavljali pomembnost družbene komponente in njene vloge. Obenem smo analizirali zavedanje o organizacijski strukturi in hierarhičnih lastnostih pobude NPPI in ocenili vrsto organizacijskega in institucionalnega okvira in popolnost na podlagi modela zrelosti (poglavje 4.1). Na koncu smo na podlagi opisa statusa razvoja NPPI analizirali potencialne učinke pristojnosti PPI in njenih sestavin na nižje hierarhične ravni (poglavje 4.2).

\subsection{Zakonski okvir in razvojna strategija}

Pobudnik za razvoj koncepta PPI v Srbiji je Republiški geodetski zavod (RGZ), ki zbira geoprostorske podatke, ki so osnova za vzpostavitev paradigme PPI (Rajabifard in ostali 2000; Nedović-Budić in ostali 2007).

V Zakonu o državni izmeri in katastru (v nadaljevanju: Zakon) (Uradni list Republike Srbije, št. 72/2009, 18/2010) je bila pobuda NPPI opredeljena kot strategija, tehnologija, pravila, standardi in človeški viri, potrebni za zbiranje, obdelavo, shranjevanje, dostopnost, izmenjavo in optimalno uporabo geoprostorskih podatkov o ozemlju Republike Srbije.

Slika 4: Z ustanovitvijo geoportala GeoSrbija bo omogočen iznos, odkrivanje, ogled in v prihodnje tudi izmenjava obstoječih geoprostorskih podatkov v Srbiji, potrebnih za izvajanje različnih nalog in postopkov. Vloga geoportala je tudi predstavitev koncepta PPI različnim udeležencem, deležnikom in srbskemu prebivalstvu na splošno (@ geoSerbia).

Glej angleški del prispevka.

Ta Zakon tudi jasno predpisuje prilagajanje prihodnjih srbskih rešitev PPI v skladu s pravili vseevropske pobude PPI, tj. direktive INSPIRE. Cilj te direktive je razvoj evropske infrastrukture za prostorske informacije, potrebne za oblikovanje okoljskih politik EU in upravljanje ustreznih aktivnosti; poleg tega evropska večnacionalna skupnost PPI gradi na skupnih pravilih za vse NPPI držav članic v domeni: metapo- 
datkov; prostorskih podatkov in storitev; mrežnih storitev in tehnologij; dogovorov o skupni uporabi, rabi in dostopu.

Nadalje zgoraj omenjeni Zakon poudarja zavezo k uvedbi sestavljenega proizvodno-procesnega razvojnega modela za NPPI, ki daje poseben poudarek sestavini ljudje in upravljanju razmerij med podatkovnimi komponentami.

Toda Zakon ne predpisuje prihodnjega hierarhičnega razvoja PPI niti ne priznava pomembnosti in učinka ravni pristojnosti PPI na prihodnji razvoj drugih.

Poleg Zakona Strategija za vzpostavitev pobude NPPI v Srbiji 2009-2012 (v nadaljevanju: Strategija) (Uradni list Republike Srbije, št. 81/2010) uporablja množinsko obliko 'mi', tj. skupno vizijo NPPI.

Ustanovljen je bil tudi Svet PPI, ki je sestavljen iz predstavnikov vseh ustreznih organov, predseduje pa mu direktor RGZ. Pred kratkim je Svet sprejel Srednjeročni program del za vzpostavitev in vzdrževanje PPI 2011-2015 in ustanovil tematske delovne skupine $z$ nalogo izvedbe in koordinacije aktivnosti nacionalnih prostorsko podatkovnih skupnosti v treh domenah: komunikacija, tehnični okvir in zakonski okvir.

Leta 2009 je bil ustanovljen tudi nacionalni geoportal GeoSrbija s poglavitnim ciljem olajšati iskanje geoprostorskih podatkov.

Preglednica 3: Zrelost pobude srbske PPI od organizacijskega vidika do vidika institucionalnega okvira (privzeto po: Kok, Van Loenen 2005, 706).

\begin{tabular}{|c|c|c|c|c|}
\hline \multirow[t]{2}{*}{ vidik } & \multicolumn{4}{|c|}{ stopnja zrelosti } \\
\hline & samostojna & izmenjava/standardizacija & vmesna stopnja & mreža \\
\hline vizija & $\begin{array}{l}\text { osredotočenost na } \\
\text { posamezno organizacijo }\end{array}$ & $\begin{array}{l}\text { razvoj z vključenostjo } \\
\text { vseh deležnikov }\end{array}$ & uvedba & $\begin{array}{l}\text { v široki skupni uporabi } \\
\text { in pogosto pregledana }\end{array}$ \\
\hline vodstvo & $\begin{array}{l}\text { osredotočenost na } \\
\text { posamezno organizacijo }\end{array}$ & vprašljivo & sprejeto & $\begin{array}{l}\text { upoštevano s strani vseh } \\
\text { deležnikov }\end{array}$ \\
\hline komunikacija & $\begin{array}{l}\text { osredotočenost na } \\
\text { posamezno organizacijo }\end{array}$ & $\begin{array}{l}\text { odprta med javnimi } \\
\text { strankami }\end{array}$ & $\begin{array}{l}\text { odprta med vsemi } \\
\text { deležniki }\end{array}$ & $\begin{array}{l}\text { odprta in interaktivna } \\
\text { med vsemi }\end{array}$ \\
\hline $\begin{array}{l}\text { zmožnost } \\
\text { samoorganizacije }\end{array}$ & $\begin{array}{l}\text { pasivno prepoznavanje } \\
\text { problema }\end{array}$ & $\begin{array}{l}\text { nevtralno prepoznavanje } \\
\text { problema }\end{array}$ & $\begin{array}{l}\text { aktivna pomoč } \\
\text { pri reševanju problemov }\end{array}$ & $\begin{array}{l}\text { aktivno delo } \\
\text { na inovacijah }\end{array}$ \\
\hline
\end{tabular}

Glede na trenutni položaj institucionalnih predpogojev in organizacijskega konteksta (Kok, Van Loenen 2005) je pobuda PPI v Srbiji v začetni, samostojni fazi zrelosti. Ceprav je na primer vizija znotraj Strategije zapisana z množinsko obliko 'mi', ta še ni bila eksplicitno sprejeta - z uradnim sporazumom o sodelovanju - kot je običajno pri drugih deležnikih PPI. Tako je vodstvo skupnosti PPI na strani večinstitucionalnega Sveta PPI dokaj neformalno in to funkcijo še vedno izvaja RGZ (Oddelek za PPI). Zato je, razen ustanovljenih delovnih skupin za komunikacijske aktivnosti, v tej fazi srbska razvojna komunikacija v povezavi s PPI $\mathrm{v}$ splošnem omejena na izpolnjevanje znotrajorganizacijskih potreb vsakega posameznega udeleženca. Zdi se, da se večina deležnikov v srbski geoprostorski skupnosti s težavami še vedno spopada zgolj pasivno, saj se osredotoča izključno na zakonsko predpisane naloge, medtem ko je zmožnost samoorganizacije skupnosti zmanjšana na minimum. Tak odnos se odraža v odsotnosti informacij o strukturiranih osrednjih metapodatkovnih elementih na geoportalu za vsak naloženi nabor podatkov in odsotnosti sistematične proizvodnje in prevzemanja skupnih prostorsko podatkovnih standardov in zakonskega okvira v Srbiji.

\subsection{Sestavine NPPI in njihovi učinki}

Podobno kot drugje tudi srbska pobuda PPI vključuje pet osnovnih sestavin (Rajabifard in ostali 2002), ki so opisane znotraj omenjene Strategije $(2010,5)$ : podatki; standardi; dostopovno omrežje; ljudje; in politika.

Vse sestavine, razen politike, predpisuje Zakon. Poleg tega zgoraj omenjeni srednjeročni program za te sestavine predvideva določeno število aktivnosti ter kratkoročnih in dolgoročnih ciljev.

Glede na že prepoznani pomembni vpliv, ki ga imajo pobude PPI na razvoj drugih pristojnosti PPI višje in nižje v hierarhiji (preglednica 2), bi lahko v primeru srbskih pristojnosti PPI pričakovali potencialni učinek na vse sestavine, razen vpliva razvoja nacionalnih temeljnih podatkov PPI na izgradnjo lokalnih. 
V odsotnosti ustreznega strateškega dokumenta v nadaljevanju podajamo analizo učinkov, ki jih imajo porajajoče sestavine PPI na hierarhično nižje ravni in na piramido PPI v Srbiji.

V zvezi s sestavino podatki ugotavljamo, da se del ključnih geopodatkov v Srbiji zbira in upravlja na nacionalni ravni, drugi pa se zbirajo in vzdržujejo na lokalni ravni, običajno znotraj organizacijskih enot, ki so del vladnih/javnih institucij, ustanovljenih na nacionalni ravni (ti ključni gepodatki vključujejo upravne meje, katastrske karte, geografska imena, rabo zemljišč, vegetacijo, topografske značilnosti itn.). Brez ustrezne podatkovne politike je stopnja skupne rabe in izmenjave geoprostorskih podatkov in informacij med in znotraj različnih ravni PPI in pristojnosti v Srbiji odvisna le od dobre volje deležnikov v PPI.

Poleg tega mora - poleg že uvedenih tehničnih standardov ISO (predpisanih z direktivo INSPIRE) za ključne metapodatke in opredelitve sheme XML na nacionalni ravni - prihodnji razvoj PPI prepoznati in prevzeti druge tehnične in netehnične standarde na vseh drugih ravneh. Ti standardi bi zagotovili trenutno manjkajočo (1) družbeno-tehnično skladnost pobude PPI v Srbiji in omogočili potrebno (2) povezovanje in medoperabilnost podatkov iz različnih virov PPI in pristojnosti na nacionalni ravni in širše (Mohammadi in ostali 2008, 404).

Ne glede na povečane potrebe po podatkih in informacijah v postopkih odločanja na lokalnih, regionalnih in nacionalnih ravneh je danes dostop do geoprostorskih podatkov v Srbiji zaradi neenakomerno razvitih mrežnih tehnologij na splošno slab (Nedović-Budić in ostali 2007). Tako bi morala prihodnja politika PPI poskrbeti, da bi bila dostopnost geopodatkov na stroškovno smotrn in učinkovit način v Srbiji neposredno odvisna od tehnoloških rešitev, ki jih je treba uvajati znotraj vsake funkcionalne plasti in organizacijske ravni (Curdt in ostali 2009).

Slika 5: Z uvedbo skupnih tehničnih standardov znotraj nove geprostorske skupnosti je zagotavljena zmožnost celostnega vpogleda, združevanja in analize različnih geoprostorskih podatkov iz različnih virov in s tem možnost sprejemanja pravih odločitev o prihodnjih aktivnostih (C) geoSerbia).

Glej angleški del prispevka.

$\mathrm{Na}$ koncu velja poudariti, da čeprav prostovoljstvo ni običajni sodelovalni model v današnji Srbiji in so čezsektorske skupine in večdisciplinarni projekti prej izjeme kot pravilo, bi morala v prihodnosti komponenta ljudje vključevati vse deležnike geoprostorske skupnosti in interesne skupine z vseh ravni in vseh pristojnosti: akterjev iz zasebnega in javnega sektorja; nacionalnih in lokalnih organizacij. To so na primer Republiška agencija za prostorsko načrtovanje, Statistični urad Republike Srbije, Fakulteta za geografijo, Geografski inštitut Jovan Cvijić, regijski organi, občine, nevladne organizacije, komercialni ponudniki podatkov, uradi za projekte, financirane iz tujine (kot so uradi GIZ, USAID, Svetovne banke in druge enote za izvajanje projektov), in drugi.

\section{Razprava: predlog srbskega institucionalnega okvira NPPI in organizacijskega modela}

Opisu trenutnih začetnih predpogojev za uvedbo koncepta PPI v Srbiji (poglavje 4.1) in analizi položaja in potreb za razvoj osnovnih sestavin PPI na vsaki ravni nacionalne pristojnosti PPI (poglavje 4.2) sledi razprava o optimalnem organizacijskem in institucionalnem kontekstu za smotrn in učinkovit razvoj PPI.

$\mathrm{Na}$ podlagi priporočil direktive INSPIRE in izkušenj držav, ki imajo najdaljšo zgodovino in so $\mathrm{v}$ ospredju razvoja PPI, kot so Norveška, Nizozemska, ZDA, Avstralija, Združeno kraljestvo, Švedska in druge (Rajabifard in ostali 2002), bi morala Srbija vložiti poseben napor v izgradnjo družbene - ljudje - komponente znotraj vseh funkcionalnih plasti pristojnosti PPI. Primeri dobre prakse iz prej omenjenih držav vključujejo: vzpostavitev neodvisnega telesa za razvoj PPI kot na primer na Nizozemskem, Norveškem ali v Avstraliji; izobraževanje zaposlenih iz različnih deležniških organizacij o mednarodno priznanih tehničnih in netehničnih standardih; uvedba predmetov na temo (N)PPI na univerze.

Čeprav so nekatere omenjene države prešle ali prehajajo iz proizvodnega na procesni razvojni model NPPI, bi morala Srbija uvesti sestavljeni proizvodno-procesni model za razvoj pobude NPPI. Sestavljeni model bi zagotovil uvedbo razvojnega modela PPI, ki bi bil dovolj učinkovit in fleksibilen za premagovanje strukturnih izzivov v Srbiji, kot so: pomanjkanje temeljnih geoprostorskih podatkov in obstoječe tehnične in netehnične nedoslednosti. Poleg omenjenih prednosti je bil (sestavljeni) model prepoznan 


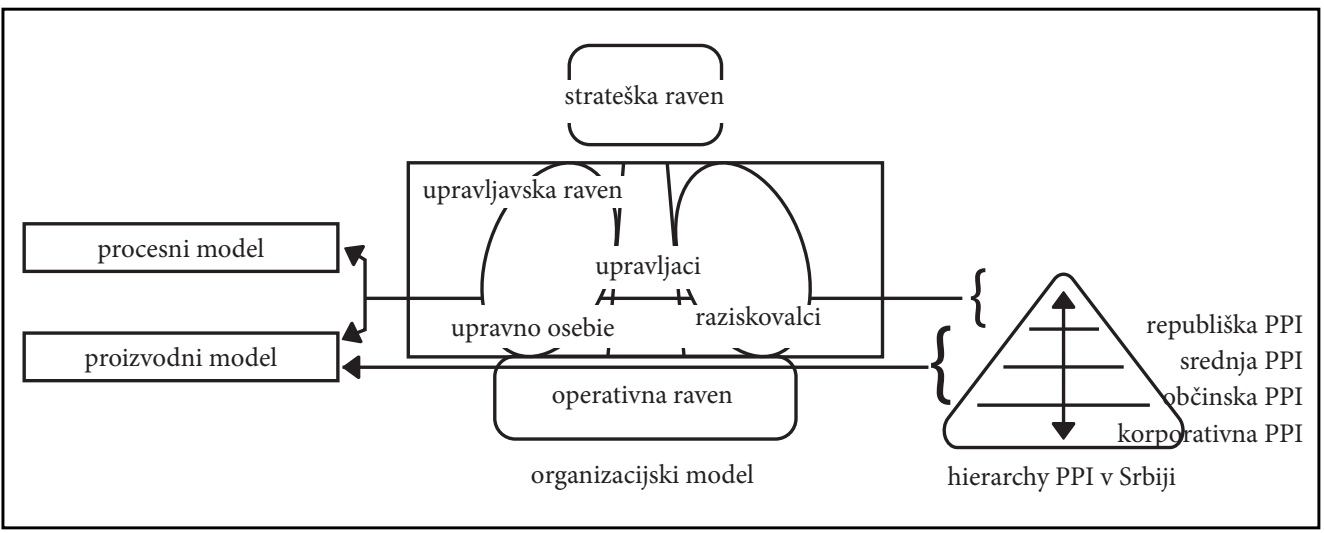

Slika 6: Splošna hierarhija NPPI z organizacijsko strukturo in razvojnima modeloma - predlog (privzeto po: Rajabifard in ostali 2002, 17; Mintzberg 1983).

kot najbolj pogosto uporabljeni model v tistih evropskih državah (Rajabifard in ostali 2002), ki so zavezane k izvajanju direktive INSPIRE, čemur naj bi sledila tudi Srbija - kot država, ki si želi članstva v Evropski uniji.

Tako bi moral predlagani sestavljeni model za srbski razvoj PPI izkoristiti prednosti obeh pristopovproizvodnega in procesnega. Seveda bodo na posameznih ravneh piramide NPPI prevladovale lastnosti enega od obeh razvojnih modelov (Mintzberg 1983; Živković 2009).

Z drugimi besedami, strateška raven organizacijskega modela NPPI (slika 3) bo morala privzeti procesni razvojni model, saj bo ta odgovorna za dolgoročne odločevalske aktivnosti, ki vključujejo:

- nastanek in izvedbo politike in strategije NPPI;

- komuniciranje in koordinacijo uresničevanja odločitev na vseh ravneh;

- koordinacijo aktivnosti delovnih skupin; in

- ustreznost odločitev za trajnost koncepta v Srbiji.

Na srednji upravljavski ravni piramide NPPI bodo morale prevladovati naloge, ki bodo ustrezale proizvodnemu modelu, saj bodo upravno osebje, upravljavci in raziskovalci na tej ravni udeleženi v kratkoročnem razvoju konkretnih storitev in proizvodov NPPI. Na splošno bi morali biti za razvoj upravljavskih orodij, potrebnih za NPPI, odgovorni upravljavci z različnih ravni in organizacij javnega sektorja iz celotne Srbije. Raziskovalci iz inštitutov, univerz in drugih organizacij, usmerjenih v znanje, bi morali biti udeleženi pri nastanku in razširjanju znanja in inovacij v smeri hitrega, smotrnega in učinkovitega razvoja NPPI. Upravno osebje z različnih ravni javnega sektorja bi prispevalo s pripravo različnih predlogov politik, katerih uvedba bi podpirala optimalne institucionalne pogoje za evolucijo pobude NPPI v Srbiji.

$\mathrm{Na}$ koncu naj poudarimo, da naj bi na operativni ravni strukture NPPI prevladovale lastnosti proizvodnega razvojnega modela. Ta raven hierarhije NPPI bi bila sestavljena iz vseh občinskih deležnikov v Srbiji, ki bi upravljali prostorsko podatkovne vire znotraj svojih pristojnosti v skladu s skupnimi standardi NPPI in postopki, predpisanimi za strateško raven, nadzor in ocenjevanje pa bi izvajala upravljavska raven (Carrera, Ferreira 2007).

\section{Sklep}

Po uradnem začetku pobude PPI v Srbiji bo treba najti ustrezen organizacijski in institucionalni okvir za zagotavljanje optimalnega razvoja in uvedbe v okviru specifičnih pogojev Srbije, predvsem glede na (1) pomanjkanje ključnih geopodatkov in (2) odsotnost medorganizacijske komunikacije in sodelovanja.

Na podlagi izkušenj in naukov iz preteklosti iz držav, ki predstavljajo primere dobre prakse v domeni razvoja NPPI, bo treba privzeti sestavljeni razvojni pristop. Na eni strani bi morala uporaba sestavljenega razvojnega modela zagotoviti uravnotežen in celosten pristop s krepitvijo lastnih zmogljivosti k organizacijski strukturi NPPI v Srbiji; tako bi se odgovornosti za razvoj vsebine NPPI (podatkovni nizi) in vzpostavitev 
poti (komunikacijski kanal, sodelovanje, dostop itn.) med deležniki PPI lahko enakovredno in optimalno delile. Po drugi strani bi moral sestavljeni model zagotavljati osveščenost in mobilizacijo komponente ljudje, ki se je izkazala kot bistvena pri doseganju ciljev koncepta PPI na splošno; udeležba že v prvih fazah procesa razvoja NPPI bi med deležniki zagotovila odgovornost, zaupanje in motivacijo.

Pred izgradnjo osnovnih sestavin NPPI in ustrezne hierarhije pristojnosti je treba opredeliti ustrezen organizacijski in institucionalni okvir z jasno opredeljenimi vlogami, pravicami, omejitvami in odgovornostmi deležnikov do podatkovne komponente. Ta okvir bi moral podpirati ključna vprašanja, kot so:

- delo Sveta PPI na najvišji strateški ravni, ki bi moral imeti močno vodilno vlogo;

- delo strokovnih delovnih skupin/projektnih skupin na srednji ravni, ki bi iskale rešitve, potrebne za doseganje prednosti NPPI v Srbiji; in

- vzpostavitev stabilnih komunikacijskih kanalov, koordinacijskih mehanizmov in zaveze k uvedbi in sprejetju standardov PPI na lokalni ravni.

V prihodnosti bi morali vpleteni akterji - pod vodstvom Sveta NPPI in koordinacijo skupne politike in strategije - oblikovati okolje, $\mathrm{v}$ katerem bi ugodili potrebam deležnikov prostorskih skupnosti in interesnih skupin, medtem ko bi bilo večanje koristi informacijske mreže in mreže znanja motiv za doseganje samoorganizacijske sposobnosti in družbe znanja v Srbiji.

$\mathrm{Na}$ koncu velja poudariti, da je za uvedbo rešitev v srbski NPPI, ki jih podajamo v tem članku, najprej treba izvesti vrsto raziskav, ki bi pokazale optimalne rešitve za vsako od sestavin PPI kot tudi za druge družbeno-tehnične pojave, povezane z razvojem in evolucijo tega koncepta.

Slika 7: Po vpostavitvi potrebnih podatkovnih baz in pridobitvi ustreznega znanja bo srbska NPPI predstavljala zanesljivo platformo za modeliranje in simulacijo realnih pojavov in njihove dinamike, končni uporabniki pa bodo razpolagali s celostnim in realnočasovnim razumevanjem svojega bivalnega okolja (@ Google).

Glej angleški del prispevka.

\section{Literatura}

Glej angleški del prispevka. 